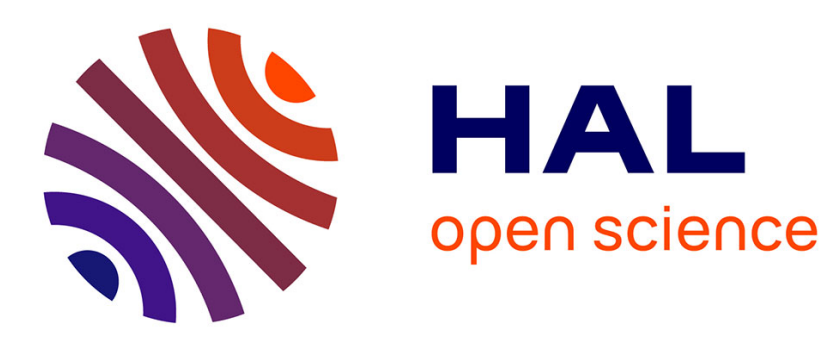

\title{
Elevation change and stability on a prograding delta
}

\author{
Wayne Wagner, Dimitri Lague, David Mohrig, Paola Passalacqua, John Shaw,
} Kevan Moffett

\section{To cite this version:}

Wayne Wagner, Dimitri Lague, David Mohrig, Paola Passalacqua, John Shaw, et al.. Elevation change and stability on a prograding delta. Geophysical Research Letters, 2017, 10.1002/2016GL072070 . insu-01477153

\section{HAL Id: insu-01477153 \\ https://hal-insu.archives-ouvertes.fr/insu-01477153}

Submitted on 27 Feb 2017

HAL is a multi-disciplinary open access archive for the deposit and dissemination of scientific research documents, whether they are published or not. The documents may come from teaching and research institutions in France or abroad, or from public or private research centers.
L'archive ouverte pluridisciplinaire HAL, est destinée au dépôt et à la diffusion de documents scientifiques de niveau recherche, publiés ou non, émanant des établissements d'enseignement et de recherche français ou étrangers, des laboratoires publics ou privés. 


\section{Geophysical Research Letters}

\author{
RESEARCH LETTER \\ 10.1002/2016GL072070 \\ Key Points: \\ - The subaerial Wax Lake Delta is \\ aggrading toward a stable elevation \\ on a time scale of 16 years \\ - Higher elevations of the delta \\ fluctuate around equilibrium as \\ change is episodic, not continuous \\ - Peaks in elevation distributions do not \\ necessarily indicate corresponding \\ elevation equilibria
}

Supporting Information:

- Supporting Information S1

Correspondence to:

W. Wagner,

wagner@utexas.edu

\section{Citation:}

Wagner, W., D. Lague, D. Mohrig, P. Passalacqua, J. Shaw, and K. Moffett (2017), Elevation change and stability on a prograding delta, Geophys. Res. Lett., 44, doi:10.1002/2016GL072070.

Received 22 NOV 2016 Accepted 8 FEB 2017 Accepted article online 9 FEB 2017

○2017. American Geophysical Union. All Rights Reserved.

\section{Elevation change and stability on a prograding delta}

\author{
Wayne Wagner $^{1}$ (D), Dimitri Lague ${ }^{2}$ (D), David Mohrig ${ }^{1}$ (D), Paola Passalacqua ${ }^{3}$ (D), John Shaw ${ }^{4}$, \\ and Kevan Moffett ${ }^{5}$ iD
}

${ }^{1}$ Department of Geological Sciences, University of Texas at Austin, Austin, Texas, USA, ${ }^{2}$ Géosciences Rennes, UMR 6118 CNRS, Université Rennes 1, Rennes, France, ${ }^{3}$ Department of Civil, Architectural, and Environmental Engineering, University of Texas at Austin, Austin, Texas, USA, ${ }^{4}$ Department of Geosciences, University of Arkansas, Fayetteville, Arkansas, USA,

${ }^{5}$ School of the Environment, Washington State University at Vancouver, Vancouver, Washington, USA

Abstract Coastal wetland systems are among the most dynamic landscapes on Earth's surface; however, interrelated processes create wetland platforms that are relatively constant in space and time. Theoretically, "stable" elevations should maintain themselves through time if the balance of processes creating that elevation remains unchanged. At Louisiana's prograding Wax Lake Delta, we measure landscape change between 2009 and 2013, quantifying volumetric changes to the delta, subaerial slope adjustment, and an equilibrium elevation of $0.56 \mathrm{~m}$ North American Vertical Datum of 1988 (where elevation change, on average, is zero), around which elevations fluctuate. We calculate a system average "equilibrium time scale" of 16 years to describe how long locations will take to approach the stable elevation. This time scale increases as a function of distance from channel edge. Peaks in elevation probability density functions can form for multiple reasons and do not require stability; e.g., peaks can temporarily form at elevations where elevation change rate is locally minimum.

\section{Introduction}

In wetland systems, relative sea level rise (the combined effect of compaction, regional subsidence, and sea level rise) and erosion tend to lower the surface elevation, while accretion of mineral sediment and organic detritus and local organic soil production increase elevation. These processes can feedback to create [e.g., Morris et al., 2002] and maintain [e.g., Defina et al., 2007; Marani et al., 2010] the stable elevations that define the marsh platform and are described by stable state theory. In this work, we develop a framework for directly analyzing landscape change on a river delta using repeat airborne lidar surveys from 2009 and 2013. We test key implications of stable state theory and describe delta evolution.

Local elevation dynamics on a coastal wetland can be defined by

$$
\frac{\partial z}{\partial t}=A-E-C-S-S L R
$$

where $z$ represents the local elevation, $t$ represents the time, $A$ is the accretion, $E$ is the erosion, $C$ is the local compaction, $S$ is the regional subsidence, and SLR is the sea level rise. We define an equilibrium elevation $\left(z_{\text {eq }}\right)$ when these forcings balance, such that

$$
\left.\frac{\partial z}{\partial t}\right|_{z=z_{\mathrm{eq}}}=0
$$

Stable elevations are the ones which will return to an equilibrium value after a small perturbation [Strogatz, 2014]. Over long time scales without major perturbations, a coastal wetland should converge toward stable elevations. Indeed, this idea has led past researchers to infer stability based on peaks in probability density functions (pdfs) of elevation without direct measurements of elevation change [Fagherazzi et al., 2006; Wang and Temmerman, 2013], especially if those peaks align with distinct vegetation zones (or unvegetated habitats) [Marani et al., 2013]. We refer the reader to Moffett et al. [2015] for a review of stable states and empirical evidence in coastal wetlands.

For coastal Louisiana, stability is crucial for the management of water, sediment, and solutes within the Mississippi River Delta (MRD), a region that is presently characterized by land loss due to a combination of factors including (1) sea level rise [Day and Templet, 1989], (2) tectonic subsidence [Dokka, 2006], (3) sediment compaction [Meckel et al., 2006; Törnqvist et al., 2008], (4) extraction of subsurface fluids and resulting 
subsidence [Morton et al., 2006], (5) segmentation of wetlands by canals [Day et al., 2000], and (6) sediment starvation by man-made levees [Day et al., 2007]. The Wax Lake Delta (WLD), a subdelta of the MRD, is an outlier within the larger system, as it is actively prograding [Shaw and Mohrig, 2013] into the relatively shallow ( $3 \mathrm{~m}$ ) Atchafalaya Bay off the coast of Louisiana, USA (Figure 1). The WLD first became subaerial during the 1973 flood of the MRD, and its subaerial fraction has grown approximately $8 \mathrm{~km}$ into the bay. The WLD is held as a real-world model for future water and sediment diversion projects aimed at land building in southern Louisiana [Kim et al., 2009; Paola et al., 2011]. For detailed information on the WLD, we refer the reader to Wellner et al. [2005] and Shaw et al. [2013].

The subaerial WLD is composed of multiple islands characterized by levees that surround lower elevation freshwater tidal wetlands and open water (Figure 1). The islands are separated by relatively deep ( 3 $\mathrm{m})$ channels that bifurcate downstream. Islands nearer the delta apex (landward islands) differ from those nearer the bay by generally having higher surface elevations and higher organic content soils (as high as $20 \%$ in the top $10 \mathrm{~cm}$ [Henry and Twilley, 2013]).

\section{Methods}

We analyze two airborne lidar surveys of WLD for landscape change and stability. The 2009 survey, flown on 14-15 January 2009, by the National Center for Airborne Laser Mapping, has a reported vertical error of $5.5 \mathrm{~cm}$ and resolution of 4.5 points $/ \mathrm{m}^{2}$ on land. The 2013 survey was flown by the Bureau of Economic Geology at the University of Texas at Austin on 13-15 February 2013, with a reported vertical error of less than $3.4 \mathrm{~cm}$ and a point density of 12.8 points $/ \mathrm{m}^{2}$ on land. The surveys were flown in winter to minimize the presence of vegetation. Even so, we filtered the lidar point clouds for returns from both trees and lower vegetation. For trees, we classified the points as trees/nontrees using the qCANUPO classifier [Brodu and Lague, 2012] within the software CloudCompare (GPL software version 2.6.2. (2016) at www.cloudcompare.org) and removed all of the tree points. To remove nontree vegetation, we filtered the elevation data within $5 \mathrm{~m}$ grid cells. Points that were $\geq 0.10 \mathrm{~m}$ above the minimum elevation for a grid cell were classified as low vegetation and removed. This filter is appropriate for the low-relief topography of the Wax Lake Delta. These "bare-earth" point clouds were coregistered vertically, using four man-made structures in three locations that are assumed not to have moved. The registered point clouds were then vertically differenced using the M3C2 function in CloudCompare [Lague et al., 2013] that averages points for each cloud within a horizontal radius that we selected as $2 \mathrm{~m}$. The difference in means of these points defines the change in elevation for that area. This approach avoids the loss of information associated with an early gridding of the individual point clouds and facilitates spatially variable error estimation by accounting for point density and point cloud roughness in the estimate of a local confidence interval for the vertical difference (see supporting information and Lague et al. [2013] for details). Wind $( \pm 0.20 \mathrm{~m})$, tides $( \pm 0.3 \mathrm{~m})$, river flow $( \pm 0.2 \mathrm{~m})$, and storms all affect water-level changes on Wax Lake Delta [O'Connor and Moffett, 2015], leading to large changes in area of exposed land due to the low relief of the system [Geleynse et al., 2015]. These factors led to more subaerial delta area surveyed in 2009 than in 2013, despite continuing delta progradation. Locations that were not subaerial during both the 2009 and 2013 surveys were not included in the differencing or in the comparisons of this study. During the period between lidar surveys, the WLD experienced one major event, the river flood in 2011 , when peak water discharge exceeded $8500 \mathrm{~m}^{3} / \mathrm{s}$. For comparison, median daily discharge on the Wax Lake Outlet at Calumet, LA (U.S. Geological Survey gaging station 07381590), for the past 15 years is $2900 \mathrm{~m}^{3} / \mathrm{s}$.

The bare-earth elevations, as well as the elevation differences, were gridded from the 2009 and 2013 point clouds using a $2 \mathrm{~m}$ pixel for ease of presentation and to remove spatial clustering bias in statistical calculations. These data from both surveys were adjusted from height above ellipsoid to North American Vertical Datum of 1988 (NAVD88) using GEOID 12B; all elevations reported in this paper are relative to NAVD88. Mean lower low water and mean sea level are roughly $-0.215 \mathrm{~m}$ NAVD88 and $+0.116 \mathrm{~m}$ NAVD88 at the apex of WLD (as per NOAA's vertical datum conversion tool; http://vdatum.noaa.gov/download.php). The 2009 lidar data were not initially classified to remove water, so we used normalized difference vegetation index from a nearly concurrent (12 January 2009) Landsat image as a stencil to remove water cells. As a second filter, we removed all points below -0.075 m NAVD from the 2009 survey. 


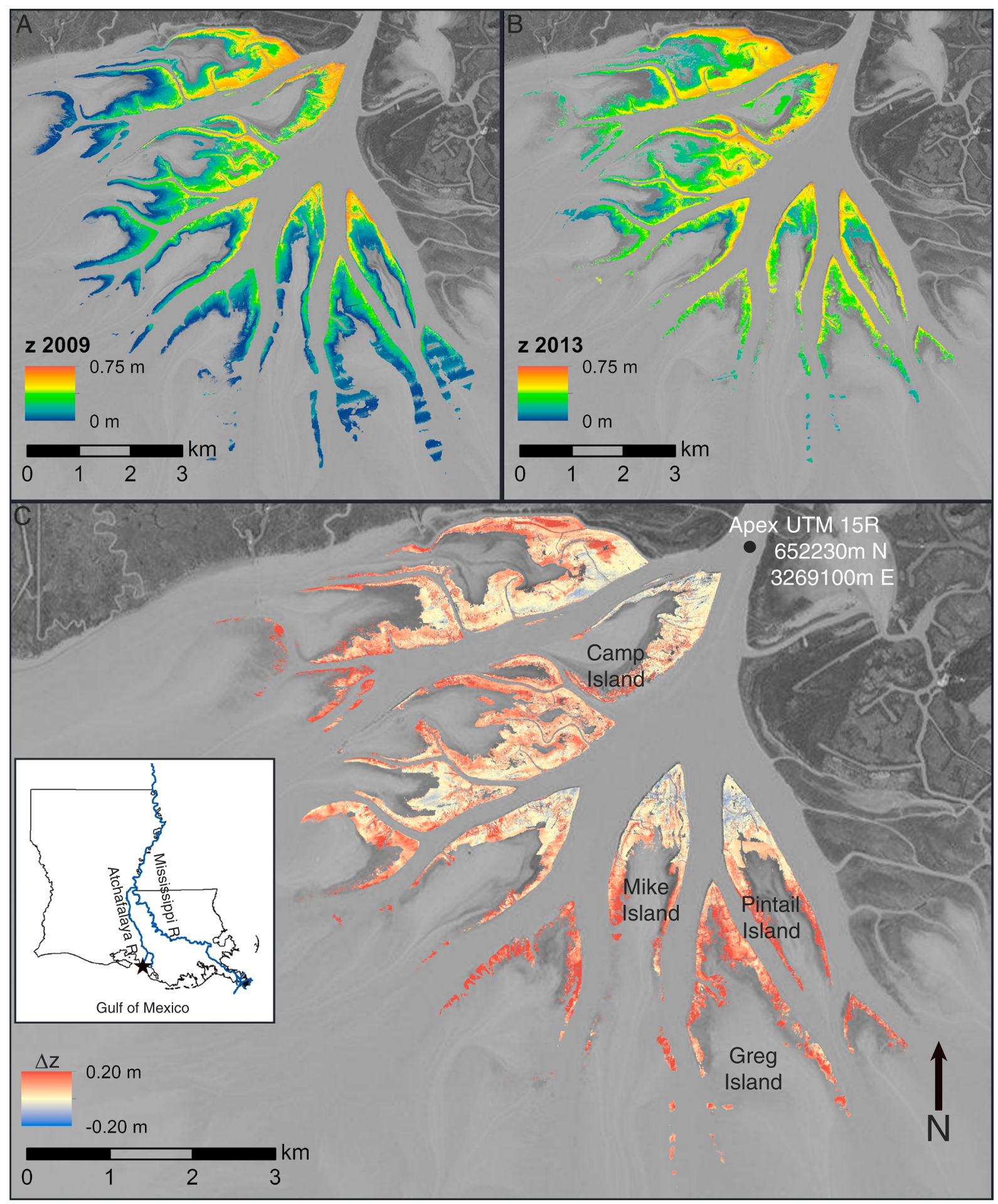

Figure 1. Wax Lake Delta elevation $(z)$ and elevation change $(\Delta z)$. (a and b) Topography of Wax Lake Delta in 2009 and 2013. Elevations are NAVD88. (c) The change in elevation on WLD between 2009 and 2013. The inset shows the location of WLD as a star in relation to Louisiana, USA. Background image source: ESRI, Digital Globe, GeoEye, Earthstar Geographics, CNES, Airbus, USDA, USGS, AEX, Getmapping, Aerogrid, IGN, IGP, swisstopo, and the GIS User Community.

The mean, median, and standard deviation of the elevation differences were $2.02 \mathrm{~cm}, 1.98 \mathrm{~cm}$, and $0.28 \mathrm{~cm}$, respectively, with correspondent mean, median, and standard deviation values for the combined error in the calculated rates of change $(\Delta z / \Delta t)$ of $0.49 \mathrm{~cm} / \mathrm{yr}, 0.48 \mathrm{~cm} / \mathrm{yr}$, and $0.07 \mathrm{~cm} / \mathrm{yr}$, respectively. The complete error analysis of these data is presented in the supporting information. 


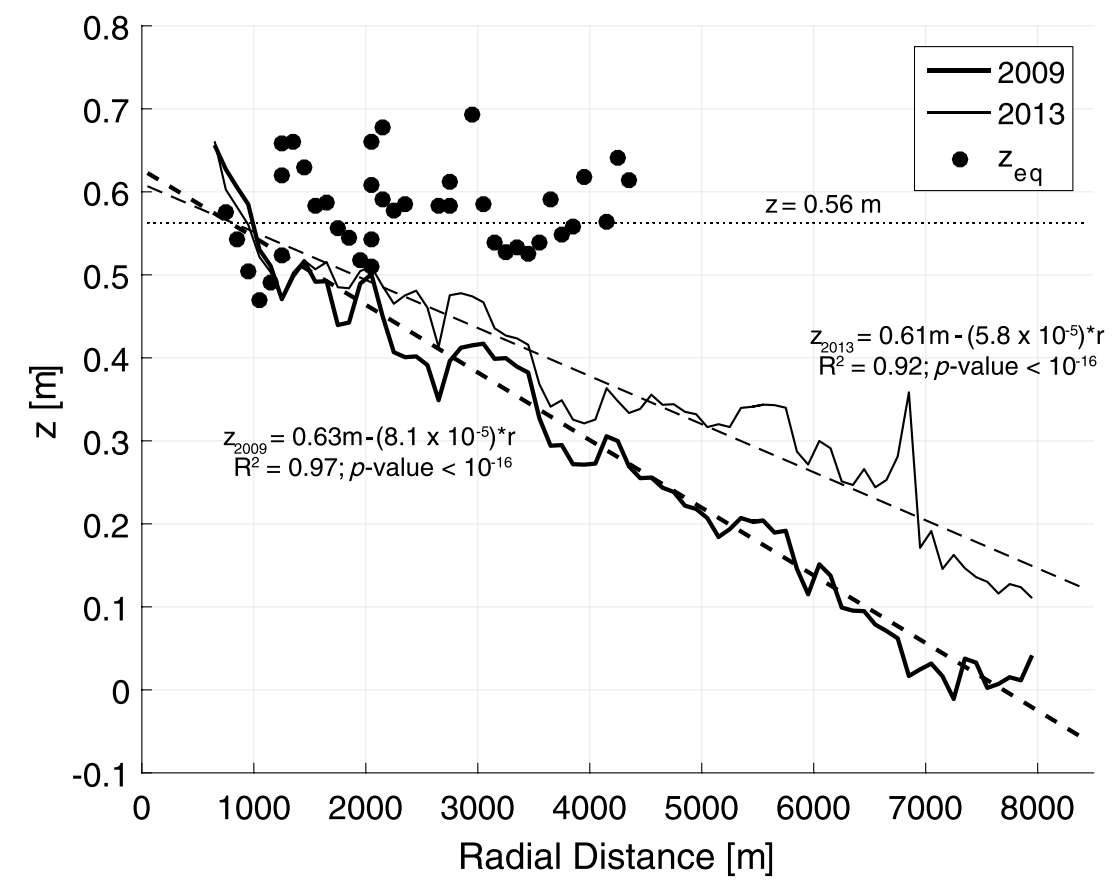

Figure 2. Slope of the Wax Lake Delta. The horizontal axis is the radial distance $(r)$ from the delta apex (UTM 15R $652,230 \mathrm{~m} \mathrm{E}$ and 3,269,100 $\mathrm{m} \mathrm{N}$ ) toward the Gulf of Mexico. The vertical axis is the elevation. The solid lines are the average elevation of all points at a given radial distance from the delta apex in 2009 (thick line) and 2013 (thin line). The dashed lines are the linear best fits. The dots represent the equilibrium elevations for a given $r$, if given enough data, as described in section 4 . We did not measure any elevation equilibria greater than $5 \mathrm{~km}$ down delta of the apex. For reference, the dotted line shows the delta-wide equilibrium elevation.

\section{Results}

Between lidar surveys, 83\% of the land surface exposed in both 2009 and 2013 of WLD experienced net aggradation, with $10 \%$ aggrading $20 \mathrm{~cm}$ or more (Figure 1c). The delta both lengthened [Shaw and Mohrig, 2013] and reduced its land-surface slope by preferentially gaining elevation bayward (Figures 1c and 2); elevation gain was greatest on down-delta islands (average change on Greg Island, a typical bayward island, was $+14.9 \mathrm{~cm}$ ) and least on up-delta islands (average change on the most landward island, Camp Island, was $+4.0 \mathrm{~cm}$ ). Associated with these elevation changes was a reduction in the radially averaged delta surface slope from $-8.1 \mathrm{~cm} / \mathrm{km}$ in 2009 to $-5.8 \mathrm{~cm} / \mathrm{km}$ in 2013 (Figure 2). The elevation mode increased from $0.18 \mathrm{~m}$ to $0.48 \mathrm{~m}$ (Figure 3a). In total, the subaerially exposed portion of WLD accumulated $6.7 \times 10^{5} \mathrm{~m}^{3}$ during the study period. For scale, volumetric change calculated between 2011 [Shaw and Mohrig, 2013] and 2015 [Shaw et al., 2016] for the $70.3 \mathrm{~km}^{2}$ subaqueous front of WLD was $1.9 \times 10^{6} \mathrm{~m}^{3}$. Subaerial deposition was $35 \%$ of subaqueous deposition for these partially overlapping 4 year periods.

To illustrate spatial variability in elevation change, we highlight the behavior of two delta islands. Camp Island (Figure 1), the most landward island, was initially high elevation on average $(44.3 \mathrm{~cm})$. However, $35.7 \%$ of the island lost elevation, and only $4.0 \%$ of the land surface aggraded more than $20 \mathrm{~cm}$. These areas of rapid aggradation were down-island levees, which were initially as much as $0.50 \mathrm{~m}$ lower than the up-island levees. Interior wetlands were comparatively stable, with some locations aggrading and some losing elevation. Greg Island (Figure 1), a bayward island, aggraded almost everywhere ( $\Delta z>0$ for $99.9 \%$ of locations), with $20.8 \%$ of the island showing elevation increases of more than $20 \mathrm{~cm}$. Unlike on landward islands, these levees were initially low $(0.109 \mathrm{~m})$ and widened through time.

Equilibrium elevations can be represented graphically [Marani et al., 2013] by plotting elevation change against elevation itself (Figures $3 c$ and $3 d$ ). Delta-wide rates of elevation change, $\Delta z / \Delta t$, plotted versus initial elevation, $z$, show elevation gain, on average, across all elevations except the very highest (Figure $3 c$ ). On average, only elevations near $0.56 \mathrm{~m}$ did not change. Locations near this equilibrium elevation were stable, as those below it tended to gain elevation, while those above this elevation tended to lose elevation. The 

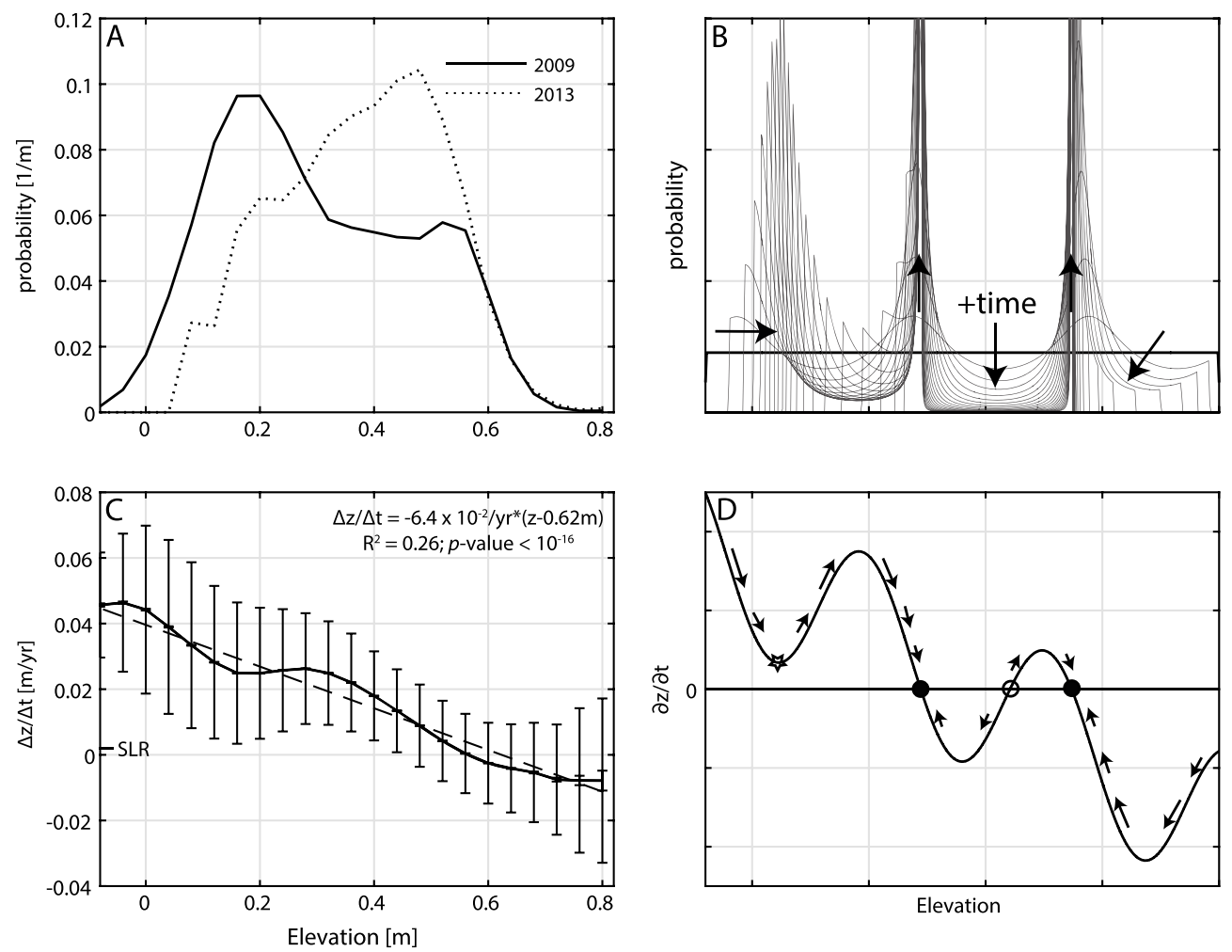

Figure 3. Probability density functions (pdfs) of elevation and stability diagrams of elevation change. (top row) The pdfs of elevation ( $z$ ) throughout the subaerial delta in (a) 2009 and 2013 and (b) theoretically. (bottom row) Rates of change of elevation as a function of elevation from (c) data and (d) theory. (Figure 3a) The pdfs of WLD elevation in 2009 and 2013. (Figure 3b) Hypothetical evolution of an initially uniform pdf (solid line) as it changes according to processes evolving multiple equilibria (change function presented in Figure 3d). The grey lines and arrows show the pdf's progression through time. (Figure 3c) Average measured rate of change of elevation $(\Delta z / \Delta t)$ on WLD as a function of initial elevation, $z$. There are two sets of error bars. The narrower error bars represent the $95 \%$ confidence interval of the mean in each bin and are often too close together to be visible. The wider error bars represent the standard deviation of the data in each bin. The dashed line represents the best fit line. The rate of sea level rise (SLR) is marked on the vertical axis. (Figure 3d) Model $\partial z / \partial t$ as a function of $z$, creating two stable equilibria (filled circles) and one unstable equilibrium (open circle) and one unstable attractor (unfilled star). This attractor is unstable because the rate of change is nonzero; however, its absolute rate of change is less than its neighbors, leading to a temporary peak in the pdf near this elevation, as shown in Figure $3 \mathrm{~b}$.

spread of the data around the $\Delta z / \Delta t$ versus $z$ line (Figure 3c), however, indicates that this trend does not fully capture the delta's dynamics. Of the points that were above the stable elevation in $2009,43.9 \%$ were below in 2013. Of the points that were above the stable elevation in $2013,47.1 \%$ were below it in 2009 . These locations "overshot" stability between 2009 and 2013.

The elevation pdfs for 2009 and 2013 (Figure 3a) were both primarily unimodal, with the mode shifting from $18 \mathrm{~cm}$ to $48 \mathrm{~cm}$. We observed three important phenomena in these pdfs. (1) The main peak in the 2013 pdf was primarily formed by aggradation of the main peak from 2009 as delta-wide elevations increased. Similar phenomena were observed by Defina et al. [2007] and Wang and Temmerman [2013]. (2) Elevation modes became better defined (i.e., pdfs are "peakier" or higher kurtosis) as the elevation approaches stability and $\partial z / \partial t$ converges. (3) The local minimum in $\Delta z / \Delta t$ (Figure 3c) formed a second peak in the 2013 elevation pdf, as discussed below.

\section{Discussion}

On WLD, sediment deposition is the major driver of aggradation [Smith, 2014]. Subaqueous regions adjacent to channels can accumulate mineral sediment quickly, since sediment supply is much larger than the system's ability to remove it [Shaw and Mohrig, 2013]. In general, higher elevations receive less mineral 
sediment due to the vertical sorting of sediment in the water column and decreased frequency of inundation [Pethick, 1993; Marani et al., 2010]. This negative feedback is likely responsible for the negative trend in $\Delta z / \Delta t$ with respect to the initial elevation, $z$ (Figure 3c). Once an aggrading bed is high enough, vegetation may establish itself, affecting future elevation changes through a number of feedbacks [Nepf, 1999; Le Hir et al., 2007; Temmerman et al., 2007]. Vegetation might decrease turbulent intensity [Leonard and Luther, 1995; Nepf, 1999; Mudd et al., 2010] or capture sediment particles [Morris et al., 2002; Le Hir et al., 2007; Mudd et al., 2010], leading to increased trapping efficiency of mineral sediment. Vegetation also leads to biogenesis of soils, a major component of accretion in Louisiana [Day et al., 2000]. These processes are spatially variable, as vegetation types establish in different areas and, more importantly, at different elevations [Carle, 2013]. These feedback potentially cause local minimums in $\Delta z / \Delta t$ with respect to $z$ (Figure 3c).

To explore how a functional relationship between $\Delta z / \Delta t$ and $z$ will affect $z$ through time, we created a synthetic $\partial z / \partial t$ function consisting of a sinusoid superposed on a negative $(\partial z / \partial t) / z$ trend (Figure $3 \mathrm{~d}$ ). This function creates three equilibria, two stable (filled dot) and one unstable (unfilled dot). Applying this function to an initially uniform distribution of elevation using a simple Euler forward method, we evolve an elevation pdf through time (Figure $3 b$ ). As expected, elevations near the stable equilibria become more frequent in time while those near the unstable equilibrium become less frequent. Notably, a transient third peak forms near a local minimum in $|\partial z / \partial t|$, marked with a star in Figure $3 \mathrm{~d}$. This peak is analogous to the second peak that formed for the WLD pdf near the saddle in $\Delta z / \Delta t$ at $z=0.18 \mathrm{~m}$ (Figures 3a and 3c). Even though a local minimum in $|\partial z / \partial t|$ is not an equilibrium point, locations will spend more time at this elevation than at higher or lower elevations due to the local minimum in aggradation rates. This convergence in $\partial z / \partial t$ at a local minimum is expressed as a peak in the pdf (Figure 3b), even if on a longer time scale, the peak is transient. Given enough time, these peaks will disappear. This highlights a previously identified challenge with interpreting multimodal elevation histograms solely in terms of multiple stable system states [Moffett et al., 2015].

Using a continuous $\partial z / \partial t$ as a model for the measured $\Delta z / \Delta t$, the relationship shown in Figure $3 c$ can be approximated as a straight line:

$$
\frac{\partial z}{\partial t}=-\gamma\left(z-z_{\text {eq }}\right)
$$

whose solution is

$$
\frac{z(t)-z_{\mathrm{eq}}}{z_{0}-z_{\mathrm{eq}}}=e^{-\gamma t}
$$

where $\gamma$, the slope of the best fit line in Figure $3 c$, is a frequency scale associated with the system establishing equilibrium. For WLD, $\gamma$ is $6.4 \times 10^{-2} / \mathrm{yr}$, equivalent to an equilibrium time scale $\left(T_{\text {eq }}=1 / \gamma\right)$ of 16 years. This time scale is an $e$-folding time scale representing how long it will take a location in the system to become $\left(1-e^{-1}\right) \times 100 \%$ closer to the equilibrium point, $z_{\text {eq }}$, under 2009-2013 forcing from any initial elevation, $z_{0}$.

This time scale can be used to separate records of change associated with external forcing of the entire delta system from topographic changes due to internally generated processes [Paola et al., 1992]. For a given location, $z(t)$ reflects all of these forces and the time scales at which they act, and $z_{\mathrm{eq}}$ is the elevation where these forces, on average, balance and is set by longer-scale behavior of the system. The calculated time scale to approach equilibrium, $T_{\text {eq, }}$ is an estimate based on the data available, which span a period that is shorter than the equilibrium time scale. This means that our estimate would vary as a function of higher-frequency events (like floods or hurricanes) even though the true equilibrium time scale should not. In general, though, the estimate should be robust if the data spans a period representative of longer time frames. Sea level rise (SLR) and regional subsidence, for example, are longer time scale processes that could affect $z_{\text {eq }}$ and $T_{\text {eq. }}$. Yet in our case, a representative SLR for the northern Gulf of Mexico at Pensacola, FL, is $2.15 \pm 0.15 \mathrm{~mm} / \mathrm{yr}$ [Kolker et al., 2011], much lower than the changes we observe (Figure 3c). Regional subsidence is not well quantified but does not alter our analysis as we have coregistered the lidar surveys with ground structures.

If equation (3) completely captured the dynamics of the entire system, locations would not be able to overshoot stability. As locations approached a stable elevation, the rate of change of the elevation would decrease to zero, preventing them from passing the stable point. In reality, change is event driven and not easily captured by steady, continuous functions. A large event can create deposits that pile above the stable point. These locations might then subside, compact, and erode back toward stability over the following years. 

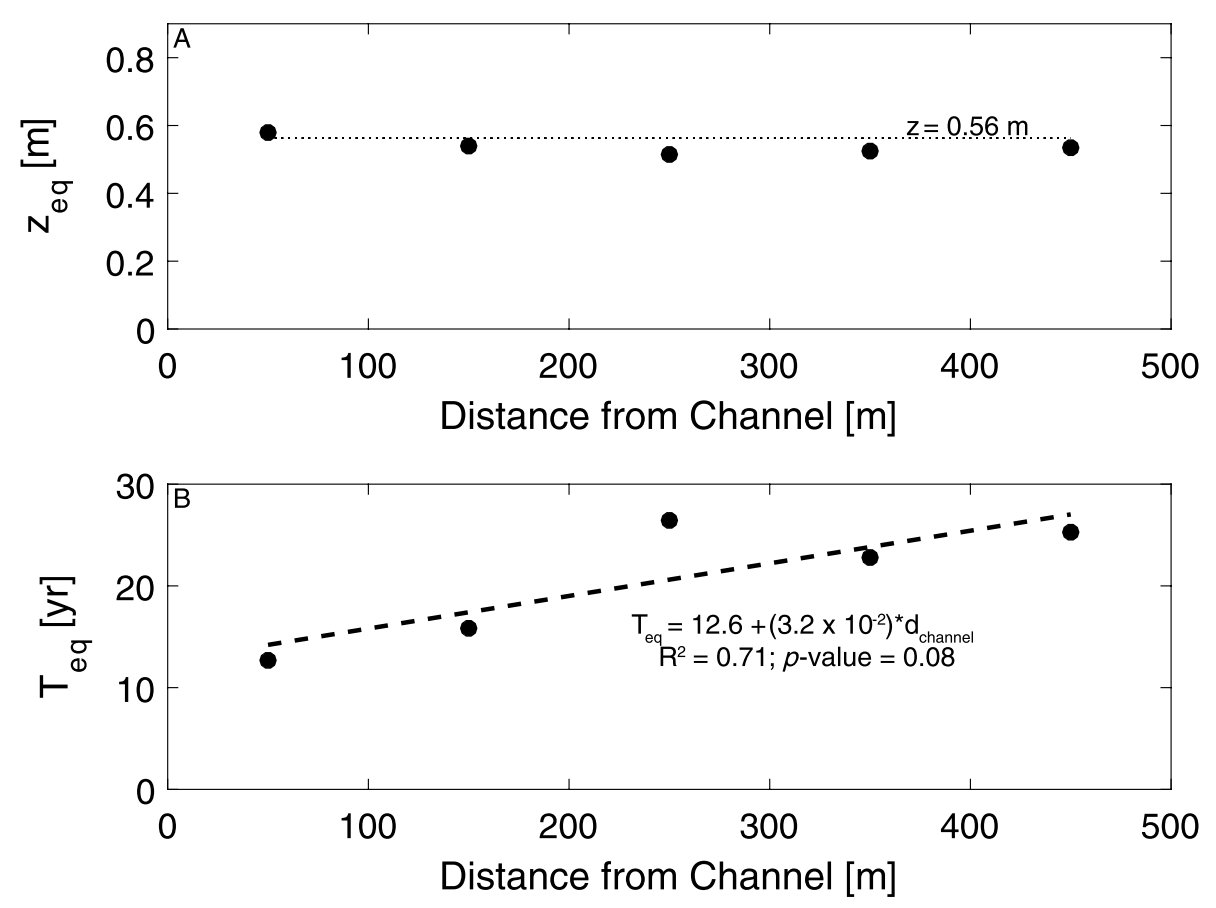

Figure 4. Equilibrium elevation and time scale analysis of the $\Delta z / \Delta t$ data binned by distance from channel edge. (a) Equilibrium elevation versus distance from channel edge. There is no significant relationship between $z_{\mathrm{eq}}$ and distance from channel edge $\left(d_{\text {channel }}\right)$. For reference, the dotted line shows the delta-wide equilibrium elevation. (b) Equilibrium time scale versus distance from channel edge. Equilibrium time scales increase for locations farther from channel edges.

Without such events, it is hard to imagine how portions of a delta that did not exist 40 years ago could be losing elevation without major shifts in forcing, but $16.8 \%$ of the WLD (and $35.7 \%$ of Camp Island) did exactly that from 2009 to 2013, suggesting that these areas may be recovering from a prior overshoot of stability.

Interestingly, equation (3) only explains $26 \%$ of the observed variation in $\Delta z / \Delta t$ (Figure 3c). We hypothesize that much of the unexplained variability is due to similar elevations existing in different subenvironments (e.g., an interior wetland on an up-delta island and an island levee on a down-delta island can have the same elevation). To test this hypothesis, we repeated the delta-wide analysis presented earlier in the manuscript but on subsections of WLD. We divided the WLD into regions defined by distance down delta or distance from a channel edge, created $\Delta z / \Delta t$ versus $z$ plots (similar to Figure $3 c$; sample plots in the supporting information) for these subsections, and solved for $z_{\text {eq }}$ (graphically) and $T_{\text {eq }}$ (using equation (3)) to evaluate how they vary spatially. The results show that $z_{\text {eq }}$ does not have a significant relationship with either radial distance from the delta apex ( $p=0.46$; plotted in Figure 2$)$ or distance from channel edge $\left(p=0.24\right.$; plotted in Figure 4a). $T_{\text {eq }}$ does not vary with distance from the delta apex ( $p=0.86$; not shown), implying that the sediment trapping efficiency of the delta is low enough that the supply does not decrease down delta. However, the distance from channel edge is a predictor of equilibrium time scale $(p=0.08$; Figure $4 b)$. The equilibrium time scale $400-500 \mathrm{~m}$ away from the nearest channel edge is double the time scale $0-100 \mathrm{~m}$ from the channel edge (Figure $4 \mathrm{~b}$ ). The interior areas are aggrading slower than the areas nearer the channels, but they are aggrading to the same elevations. This is due to physical processes that vary with respect to distance from channel. For example, sediment supply might have decreased with distance from the channel, as observed by Pizzuto [1987], Asselman and Middelkoop [1995], and Törnqvist and Bridge [2002], among others. Further, systematic reduction in the amount of sand with distance from a channel edge should lead to a spatial change in compaction rates. Regardless, the variation in equilibrium time scale largely explains the delta's current morphology. Areas near channel edges have reached equilibrium if they are up delta enough (and became subaerial early). Interior areas, on the other hand, have not reached equilibrium, for the most part, because they are aggrading slower (and did not become subaerial early). 


\section{Conclusions}

The WLD is morphodynamically active, with most of the system's elevation converging toward one equilibrium elevation, $0.56 \mathrm{~m}$ NAVD88. This equilibrium elevation does not have a significant relationship with either radial distance from the delta apex or distance from the channel edge toward island interiors. Volumetrically, most of the change on WLD is occurring down delta, while up-delta locations are nearer the equilibrium elevation. We propose an "equilibrium time scale" to estimate how long subaerial locations within the system will take to approach a stable elevation and calculate it for the WLD (16 years). This time scale increases as a function of distance to channel edge, as interior wetlands aggrade slower and therefore require longer to approach equilibrium.

Delta-wide points near the equilibrium elevation are not static. At the WLD equilibrium elevation, the standard deviation of $\Delta z / \Delta t$ is almost $2 \mathrm{~cm} / \mathrm{yr}$, and many points near this "stable" elevation overshot it between 2009 and 2013. We posit that true wetland stability is one of the dynamic stabilities, wherein many locations on a morphodynamically active coastal wetland oscillate around the stable point on time scales characteristic of the geomorphic system. Both allogenic (river, winds, tides, sediment supply, regional subsidence, etc.) and autogenic (sediment routing, vegetation, compaction, landscape form, etc.) processes would affect this time scale through event-driven aggradation/erosion and the long-term sinking of the platform. The continuous functions of equilibrium state theory are very useful for posing conceptual hypotheses and parameterizing general models, but equilibrium state behaviors present differently in empirical data, particularly over small time scales relative to the equilibrium time scale. Indeed, we demonstrate that peaks in the elevation pdf can be formed without stability through either local minimums in elevation change rates or aggradation of an initial peak in a system that has not yet had time to reach equilibrium.

\section{Acknowledgments}

This study was supported by the National Science Foundation via the Delta Dynamics Collaboratory (EAR1135427) and the University of Texas at Austin, Jackson School of Geosciences. The lidar data and the associated raste files used for this work were uploaded to OpenTopography (http://www.opentopography.org/) and are freely available (Wax Lake Delta, LA, USA, 2009, doi:10.5069/G95M63M8; Wax Lake Delta, LA, USA, 2013, doi:10.5069/ G9SF2T41). We would like to thank Kutalmis Saylam for the help in gathering and processing the 2013 lidar data, John Andrews for the help with geoid corrections, Doug Jerolmack for an interesting conversation, Tim Goudge for the help in creating beautiful figures, and two anonymous reviewers for their constructive comments that greatly improved the manuscript.

\section{References}

Asselman, N. E. M., and H. Middelkoop (1995), Floodplain sedimentation: Quantities, patterns and processes, Earth Surf. Process. Landforms, 20(6), 481-499, doi:10.1002/esp.3290200602.

Brodu, N., and D. Lague (2012), 3D terrestrial lidar data classification of complex natural scenes using a multi-scale dimensionality criterion: Applications in geomorphology, ISPRS J. Photogramm. Remote Sens., 68, 121-134, doi:10.1016/j.isprsjprs.2012.01.006.

Carle, M. V. (2013), Accretion and vegetation community change in the Wax Lake Delta following the historic 2011 Mississippi River flood, J. Coast. Res., 31, 569-587, doi:10.2112/JCOASTRES-D-13-00109.1.

Day, J. W., Jr., and P. H. Templet (1989), Consequences of sea level rise: Implications from the Mississippi Delta, Coast. Manag., 17(3), 241-257, doi:10.1080/08920758909362088.

Day, J. W., L. D. Britsch, S. R. Hawes, G. P. Shaffer, D. J. Reed, and D. Cahoon (2000), Pattern and process of land loss in the Mississippi Delta: A spatial and temporal analysis of wetland habitat change, Estuaries, 23(4), 425-438, doi:10.2307/1353136.

Day, J. W., et al. (2007), Restoration of the Mississippi Delta: Lessons from Hurricanes Katrina and Rita, Science, 315(5819), 1679-1684, doi:10.1126/science.1137030.

Defina, A., L. Carniello, S. Fagherazzi, and L. D'Alpaos (2007), Self-organization of shallow basins in tidal flats and salt marshes, J. Geophys. Res., 112, F03001, doi:10.1029/2006JF000550.

Dokka, R. K. (2006), Modern-day tectonic subsidence in coastal Louisiana, Geology, 34(4), 281-284, doi:10.1130/G22264.1.

Fagherazzi, S., L. Carniello, L. D'Alpaos, and A. Defina (2006), Critical bifurcation of shallow microtidal landforms in tidal flats and salt marshes, Proc. Natl. Acad. Sci. U.S.A., 103(22), 8337-8341, doi:10.1073/pnas.0508379103.

Geleynse, N., M. Hiatt, H. Sangireddy, and P. Passalacqua (2015), Identifying environmental controls on the shoreline of a natural river delta, J. Geophys. Res. Earth Surf., 120, 877-893, doi:10.1002/2014JF003408.

Glennie, C. (2008), Rigorous 3D error analysis of kinematic scanning lidar systems, J. Appl. Geodesy Jag, 1(3), 147-157, doi:10.1515/ jag.2007.017.

Henry, K. M., and R. R. Twilley (2013), Nutrient biogeochemistry during the early stages of delta development in the Mississippi River Deltaic Plain, Ecosystems, 17(2), 327-343, doi:10.1007/s10021-013-9727-3.

Joerg, P. C., F. Morsdorf, and M. Zemp (2012), Uncertainty assessment of multi-temporal airborne laser scanning data: A case study on an Alpine glacier, Remote Sens. Environ., 127, 118-129, doi:10.1016/j.rse.2012.08.012.

Kim, W., D. Mohrig, R. Twilley, C. Paola, and G. Parker (2009), Is it feasible to build new land in the Mississippi River Delta?, Eos. Trans. AGU, 90(42), 373-374, doi:10.1029/2009EO420001.

Kolker, A. S., M. A. Allison, and S. Hameed (2011), An evaluation of subsidence rates and sea-level variability in the northern Gulf of Mexico, Geophys. Res. Lett., 38, L21404, doi:10.1029/2011GL049458.

Lague, D., N. Brodu, and J. Leroux (2013), Accurate 3D comparison of complex topography with terrestrial laser scanner: Application to the Rangitikei canyon (N-Z), ISPRS J. Photogramm. Remote Sens., 82, 10-26, doi:10.1016/j.isprsjprs.2013.04.009.

Le Hir, P., Y. Monbet, and F. Orvain (2007), Sediment erodability in sediment transport modelling: Can we account for biota effects?, Cont. Shelf Res., 27(8), 1116-1142, doi:10.1016/j.csr.2005.11.016.

Leonard, L. A., and M. E. Luther (1995), Flow hydrodynamics in tidal marsh canopies, Limnol. Oceanogr., 40(8), 1474-1484, doi:10.4319/ lo.1995.40.8.1474.

Marani, M., A. D'Alpaos, S. Lanzoni, L. Carniello, and A. Rinaldo (2010), The importance of being coupled: Stable states and catastrophic shifts in tidal biomorphodynamics, J. Geophys. Res., 115, F04004, doi:10.1029/2009JF001600.

Marani, M., C. D. Lio, and A. D'Alpaos (2013), Vegetation engineers marsh morphology through multiple competing stable states, Proc. Natl. Acad. Sci. U.S.A., 110(9), 3259-3263, doi:10.1073/pnas.1218327110. 
Meckel, T. A., U. S. ten Brink, and S. J. Williams (2006), Current subsidence rates due to compaction of Holocene sediments in southern Louisiana, Geophys. Res. Lett., 33, L11403, doi:10.1029/2006GL026300.

Moffett, K. B., W. Nardin, S. Silvestri, C. Wang, and S. Temmerman (2015), Multiple stable states and catastrophic shifts in coastal wetlands: Progress, challenges, and opportunities in validating theory using remote sensing and other methods, Remote Sens. (Basel), $7(8)$, $10,184-10,226$

Morris, J. T., P. V. Sundareshwar, C. T. Nietch, B. Kjerfve, and D. R. Cahoon (2002), Responses of coastal wetlands to rising sea level, Ecology, 83(10), 2869-2877, doi:10.1890/0012-9658(2002)083[2869:ROCWTR]2.0.CO;2.

Morton, R. A., J. C. Bernier, and J. A. Barras (2006), Evidence of regional subsidence and associated interior wetland loss induced by hydrocarbon production, Gulf Coast region, USA, Environ. Geol., 50(2), 261-274, doi:10.1007/s00254-006-0207-3.

Mudd, S. M., A. D'Alpaos, and J. T. Morris (2010), How does vegetation affect sedimentation on tidal marshes? Investigating particle capture and hydrodynamic controls on biologically mediated sedimentation, J. Geophys. Res., 115, F03029, doi:10.1029/2009JF001566.

Nepf, H. M. (1999), Drag, turbulence, and diffusion in flow through emergent vegetation, Water Resour. Res., 35(2), 479-489, doi:10.1029/ 1998 WR900069.

O'Connor, M. T., and K. B. Moffett (2015), Groundwater dynamics and surface water-groundwater interactions in a prograding delta island, Louisiana, USA, J. Hydrol., 524, 15-29, doi:10.1016/j.jhydrol.2015.02.017.

Paola, C., P. L. Hellert, and C. L. Angevine (1992), The large-scale dynamics of grain-size variation in alluvial basins. I: Theory, Basin Res., 4(2) 73-90.

Paola, C., R. R. Twilley, D. A. Edmonds, W. Kim, D. Mohrig, G. Parker, E. Viparelli, and V. R. Voller (2011), Natural processes in delta restoration: Application to the Mississippi Delta, Ann. Rev. Mar. Sci, 3(1), 67-91, doi:10.1146/annurev-marine-120709-142856.

Pethick, J. (1993), Shoreline adjustments and coastal management: Physical and biological processes under accelerated sea-level rise, Geogr. J., 159(2), 162, doi:10.2307/3451406.

Pizzuto, J. E. (1987), Sediment diffusion during overbank flows, Sedimentology, 34(2), 301-317, doi:10.1111/j.1365-3091.1987.tb00779.x.

Shaw, J. B., and D. Mohrig (2013), The importance of erosion in distributary channel network growth, Wax Lake Delta, Louisiana, USA, Geology, G34751, 1, doi:10.1130/G34751.1.

Shaw, J. B., D. Mohrig, and S. K. Whitman (2013), The morphology and evolution of channels on the Wax Lake Delta, Louisiana, USA, J. Geophys. Res. Earth Surf., 118, 1562-1584, doi:10.1002/jgrf.20123.

Shaw, J. B., F. Ayoub, C. E. Jones, M. P. Lamb, B. Holt, R. W. Wagner, T. S. Coffey, J. A. Chadwick, and D. Mohrig (2016), Airborne radar imaging of subaqueous channel evolution in Wax Lake Delta, Louisiana, USA, Geophys. Res. Lett., 43, 5035-5042, doi:10.1002/2016GL068770.

Smith, B. C. (2014), The effects of vegetation on island geomorphology in the Wax Lake Delta, Louisiana, Thesis, 11 June.

Strogatz, S. H. (2014), Nonlinear Dynamics and Chaos: With Applications to Physics, Biology, Chemistry, and Engineering, 2 ed., Westview Press, Boulder, Colo.

Temmerman, S., T. J. Bouma, J. V. de Koppel, D. V. der Wal, M. B. D. Vries, and P. M. J. Herman (2007), Vegetation causes channel erosion in a tidal landscape, Geology, 35(7), 631-634, doi:10.1130/G23502A.1.

Törnqvist, T. E., and J. S. Bridge (2002), Spatial variation of overbank aggradation rate and its influence on avulsion frequency, Sedimentology, 49(5), 891-905, doi:10.1046/j.1365-3091.2002.00478.x.

Törnqvist, T. E., D. J. Wallace, J. E. A. Storms, J. Wallinga, R. L. van Dam, M. Blaauw, M. S. Derksen, C. J. W. Klerks, C. Meijneken, and E. M. A. Snijders (2008), Mississippi Delta subsidence primarily caused by compaction of Holocene strata, Nat. Geosci., 1(3), 173-176, doi:10.1038/ngeo129.

Wang, C., and S. Temmerman (2013), Does biogeomorphic feedback lead to abrupt shifts between alternative landscape states?: An empirical study on intertidal flats and marshes, J. Geophys. Res. Earth, 118, 229-240, doi:10.1029/2012JF002474.

Wellner, R., R. Beaubouef, J. V. Wagoner, H. Roberts, and T. Sun (2005), Jet-plume depositional bodies-The primary building blocks of Wax Lake Delta, Trans. Gulf Coast Assoc. Geol. Soc., 55, 867-909. 